\title{
Influence Of Peat Water On Mechanical Properties Of Coconut Shell And Fly Ash Based Concrete
}

\section{Analisa Pengaruh Air Gambut Terhadap Sifat Mekanik Bata Beton Berbahan Limbah Tempurung Kelapa Dan Abu Terbang}

\author{
Yulin Patrisia, Topan Eka Putra \\ 1), 2) Program Studi Pendidikan Teknik Bangunan, Fakultas Keguruan dan Ilmu Pendidikan \\ Universitas Palangka Raya, Kampus Unpar Tunjung Nyaho, Jl. H. Timang, 73111A \\ e-mail: yulin.patrisia@ptb.upr.ac.id
}

\begin{abstract}
This study aimed to determine the influence of peat water on the mechanical properties of the paving block (compressive strength and water absorption) using coconut shell waste and fly ash as raw material. The background of the research were the lack utilization of fly ash, preparation for the handling and utilization of fly ash from power station at Pulang Pisau and Tumbang Kajuei (under construction), and the utilization of coconut shell to be more effective and economical. Paving block specimens were immersed in peat water to determine the effect of peat water and the rest were immersed in plain water. This experiment used fly ash as a partial replacement of cement and $2 \%$ coconut shell as a partial replacement of fine aggregate.

The results of the analysis showed that: (a) Paving block using fly ash and coconut shells which were immersed in plain water experienced the increase in compressive strength and the decrease in water; (b) Paving block using fly ash and coconut shells soaked in peat water showed that by the increase of age, compressive strength was decrease and water absorption was increase; (c) The compressive strength of paving block specimens immersed in plain water and peat water showed relatively similar values at 7 and 28 days age, (d). Water absorption in paving block specimens soaked both in plain water and peat water showed relatively similar values at 7 days age, but at 28 days age the specimens immersed in peat water had greater water absorption.
\end{abstract}

Keywords: paving block, fly ash, coconut shell

\begin{abstract}
ABSTRAK
Penelitian ini bertujuan untuk mengetahui bagaimana pengaruh air gambut terhadap karakteristik mekanik bata beton yang dihasilkan (kuat tekan dan daya serap air) dengan menggunakan limbah tempurung kelapa dan abu terbang sebagai bahan bakunya. Latar belakang penelitian adalah karena limbah abu terbang cenderung menumpuk, kurangnya pemanfaatan yang efektif, kemudian persiapan untuk penanganan dan pemanfaatan limbah abu terbang hasil pembakaran batu bara di PLTU Pulang Pisau dan PLTU di Desa Tumbang Kajuei (dalam tahap pembangunan), serta pemanfaatan limbah tempurung kelapa agar lebih efektif dan ekonomis. Bata beton yang dibuat akan direndam dalam air gambut untuk mengetahui pengaruh air gambut terhadap karakteristik bata beton, sebagai pembanding, benda uji akan direndam pada air biasa. Penelitian ini menggunakan abu terbang sebagai pengganti sebagian semen, dan tempurung kelapa sebesar $2 \%$ sebagai pengganti sebagian agregat halus.

Hasil analisa memperlihatkan: (a) pada bata beton dengan menggunakan abu terbang dan tempurung kelapa dan direndam pada air biasa, memperlihatkan karakteristik dimana seiring dengan peningkatan umur, maka kuat tekan meningkat, dan daya serap air menurun; (b) pada bata beton dengan menggunakan abu terbang dan tempurung kelapa dan direndam pada air gambut, memperlihatkan karakteristik dimana dengan peningkatan umur, maka kuat tekan menurun, dan daya serap air meningkat; (c) kuat tekan pada benda uji bata beton yang direndam dengan air biasa dan air gambut memperlihatkan nilai yang relatif sama pada umur 7 dan 28 hari, (d). daya serap air pada benda uji bata beton yang direndam dengan air biasa dan air gambut memperlihatkan nilai yang relatif sama pada umur 7 hari, tetapi pada umur 28 hari, benda uji yang direndam dengan air gambut mempunyai daya serap air yang lebih besar dibanding dengan yang direndam pada air biasa.
\end{abstract}

Kata kunci: bata beton, abu terbang, tempurung kelapa

\section{PENDAHULUAN}

Bata beton merupakan suatu komposisi bahan bangunan yang dibuat dari campuran semen portland atau bahan perekat hidrolis sejenisnya, air, dan agregat dengan atau tanpa bahan tambahan lainnya yang tidak mengurangi mutu beton itu (SNI 03-0691-1996) [1]. Bata beton banyak digunakan untuk perkerasan jalan seperti trotoar, areal parkiran, jalanan pemukiman atau komplek perumahan, taman, dan lain-lain. Selain digunakan untuk perkerasan bata beton juga berguna untuk penyerapan air. Biasanya bata beton dibuat dari bahan dasar semen, pasir, agregat, dan air. Salah satu bahan yang dapat 
digunakan sebagai bahan tambahan penyusun bata beton adalah sisa pembakaran batu bara berupa abu terbang.

Di Indonesia, abu terbang merupakan limbah yang dihasilkan sebagian besar dari pembakaran batu bara di perusahaan pembangkit listrik tenaga uap (PLTU). Limbah batubara pada tahun-tahun mendatang dipastikan semakin meningkat jumlahnya, hal tersebut seiring dengan program penyediaan tenaga listrik $35.000 \mathrm{MW}$ yang dicanangkan pemerintah, dimana $60 \%$ pembangkit listrik tersebut menggunakan batu bara sebagai bahan bakar, dan sisanya menggunakan gas dan enegi baru terbarukan. Dengan adanya rencana penambahan 35.000 MW dimana 60\% PLTU, maka dibutuhkan tambahan batubara sekitar 100 juta ton per tahun. Di Kalimantan Tengah sendiri terdapat PLTU yang mulai beroperasi dan bertempat di Kabupaten Pulang Pisau (berlokasi $\pm 90 \mathrm{~km}$ dari kota Palangka Raya). Di Desa Tumbang Kajuei, Kecamatan Rungan, Kabupaten Gunung Mas juga sedang dibangun PLTU berkapasitas 2x100 MW yang dikembangkan oleh PT SKS Listrik Kalimantan (SLK) yang ditargetkan siap beroperasi di akhir 2019 [2].

Dari sejumlah pemakaian batubara dalam PLTU, akan dihasilkan abu batubara 2-10\% tergantung jenis batubaranya (low calory atau high calory), dengan komposisi $10-20 \%$ berupa bottom ash, sedang sisanya $80-$ $90 \%$ berupa abu terbang [3]. Sebagai gambaran, PLTU 50 MW yang menggunakan batubara sebanyak 210,1 ton/hari menghasilkan abu terbang sebanyak $17284,65 \mathrm{~kg}$ [4].

Abu terbang dikategorikan sebagai limbah B3 karena terdapat kandungan oksida logam berat dan mencemari lingkungan. Peningkatan jumlah pembangunan PLTU berbahan bakar batu bara di Indonesia menyebabkan jumlah limbah abu terbang juga akan meningkat. Jika limbah ini tidak dimanfaatkan maka akan menyebabkan masalah pencemaran lingkungan.

Berdasarkan penelitian yang dilakukan oleh Kristanto [5] tentang penggunaan abu terbang untuk pembuatan bata beton, diperoleh bahwa abu terbang dapat digunakan sebagai pengganti komponen pasir, dengan hasil tes kuat tekan rata-rata yang lebih baik sebesar $11,52 \%$. Komposisi abu terbang yang paling efektif dalam menggantikan pasir adalah $40 \%$, dan peningkatan kekuatan yang dihasilkan sebesar $43.09 \%$. Faktor yang memiliki pengaruh terbesar bagi penyerapan air dan kuat tekan.

Pada penelitian ini juga akan digunakan limbah tempurung kelapa sebagai pengganti agregat halus untuk membuat bata beton. Tempurung kelapa yang biasa disebut batok kelapa merupakan limbah kulit terdalam dari buah kelapa yang memiliki sifat kekerasan yang cukup tinggi. Limbah ini belum dimanfaatkan secara maksimal, sejauh ini banyak digunakan untuk membuat arang aktif.

Berdasarkan penelitian yang telah dilakukan oleh Kukuh Hartanto [6] tentang pemanfaatan limbah pecahan tempurung kelapa sebagai bahan tambah pada campuran bahan baku batako dengan persentase penambahan pecahan tempurung kelapa sebanyak $0 \%, 1 \%, 2 \%, 3 \%$ dan $4 \%$, diperoleh bahwa batako dengan nilai faktor ar semen (fas) 0,4 pada penambahan pecahan tempurung kelapa $1 \%$ menghasilkan nilai kuat tekan batako sebesar 7,168 MPa dan pada penambahan pecahan tempurung kelapa $2 \%$ dan $3 \%$ nilai kuat tarik belah batako sebesar 0,467 MPa.

Indonesia adalah salah satu negara yang memiliki kawasan hutan gambut yang luas. Hutan rawa gambut mencakup ekosistem utama di Indonesia dan berkisar antara 16,5-27 juta hektar, khususnya di pulau Kalimantan dan pulau Sumatera. Beberapa hutan gambut telah dikonversi karena pertumbuhan pembangunan perumahan, infrastruktur, kawasan industri, dan lain-lain. Dalam hal konstruksi di daerah gambut harus mempertimbangkan kondisi lingkungan asam, terutama untuk konstruksi yang bersentuhan langsung dengan tanah dan air tanah, oleh karena itu bahan konstruksi yang digunakan harus memiliki ketahanan yang baik terhadap lingkungan air gambut.

Berdasarkan beberapa latar belakang yang disebutkan, dimana limbah abu terbang cenderung menumpuk, kurangnya pemanfaatan yang efektif, kemudian persiapan untuk penanganan dan pemanfaatan limbah abu terbang hasil pembakaran batu bara dari PLTU Pulang Pisau dan PLTU di Desa Tumbang Kajuei, serta pemanfaatan limbah tempurung kelapa agar lebih efektif dan ekonomis, maka dirasa perlu adanya usaha untuk memanfaatkan limbah abu terbang dan tempurung kelapa dalam rekayasa material kontruksi untuk menghasilkan material yang murah dan ramah lingkungan, yaitu bata beton, di mana beberapa penelitian rujukan sudah membuktikan bahwa limbah tersebut mempunyai potensi yang baik dalam pembuatan material beton. Selain itu, karena lahan kontruksi saat ini merupakan lahan gambut, maka perlu diteliti bagaimana pengaruh gambut terhadap kekuatan bata beton. Penelitian ini bertujuan untuk mengetahui bagaimana karakteristik mekanik bata beton yang dihasilkan (kuat tekan dan daya serap air) dengan menggunakan limbah tempurung kelapa dan abu terbang sebagai bahan bakunya. Penelitian ini akan menggunakan abu terbang sebagai pengganti sebagian semen, dan tempurung kelapa sebagai pengganti sebagian agregat halus pada pembuatan bata beton. Benda uji yang ada akan direndam dengan air biasa dan air gambut untuk mengetahui pengaruhnya terhadap kuat tekan bata beton.

Tujuan penelitian adalah mengetahui bagaimana pengaruh air gambut terhadap karakteristik mekanik bata beton yang dihasilkan yaitu kuat tekan dan daya serap air dengan menggunakan limbah tempurung kelapa dan abu terbang dalam campuran pembuatan bata beton.

Isu lingkungan saat ini sudah menjadi isu global, dimana hampir disemua aspek kehidupan, sangat 
diharapkan memperhatikan keberlangsungan lingkungan sekitar. Dalam dunia konstruksi, pemakaian material yang ramah lingkungan menjadi salah satu target yang diteliti, terutama pada pemakaian limbah. Penelitian ini memanfaatkan dua jenis limbah, yaitu abu terbang dan pecahan tempurung kelapa untuk menghasilkan produk bata beton. Selain itu, telah diteliti aspek pengaruh air gambut terhadap ketahanan material, mengingat Indonesia memiliki lahan gambut yang sangat luas, yang sekarang mulai banyak dibuka untuk pembangunan infrastruktur. Diharapkan penelitian ini sangat berguna untuk menghasilkan produk material konstruksi yang murah, ramah lingkungan dan tahan terhadap lingkungan ekstrim, seperti gambut.

\section{METOdOLOGI PENELITIAN \\ Bahan Penelitian}

Pada penelitian bata beton campuran tanah, abu terbang dan kapur ini digunakan bahan-bahan sebagai berikut: (a) semen jenis PCC (Portland Composite Cement), (b) abu terbang berasal dari limbah PLTU AsamAsam, Kalimantan Selatan, (c) agregat halus yang digunakan dalam penelitian ini adalah pasir yang berasal dari Palangka Raya, Kalimantan Tengah, (d) tempurung kelapa berasal dari pasar tradisional yang berasal dari kota Palangka Raya, Kalimantan Tengah, (e). air yang digunakan adalah air bersih yang tidak mengandung lumpur, minyak dan tidak mengandung garam serta zatzat yang dapat merusak bata beton, (f) air gambut diambil dari daerah Palangka Raya, Kalimantan Tengah

\section{Peralatan Penelitian}

Adapun peralatan yang digunakan dalam penelitian ini antara lain mesin press bata beton, satu set saringan, timbangan, hydraulic press, $\mathrm{pH}$ meter digital, alat bantu diantaranya adalah gelas ukur, mistar, alat uji berat jenis, sendok semen, sekop, palu serta troli dorong.

\section{Pelaksanaan Penelitian}

Pelaksanaan penelitian ini meliputi beberapa tahap antara lain:

1. Persiapan bahan

Semua bahan yang diperlukan dalam penelitian ini dipersiapkan, seperti semen, pasir, tempurung kelapa, abu terbang dan air. Untuk persiapan material tempurung kelapa ditumbuk hingga mempunyai ukuran butir lebih kecil dari 3/16 inci atau $5 \mathrm{~mm}$ (lolos saringan no. 4).

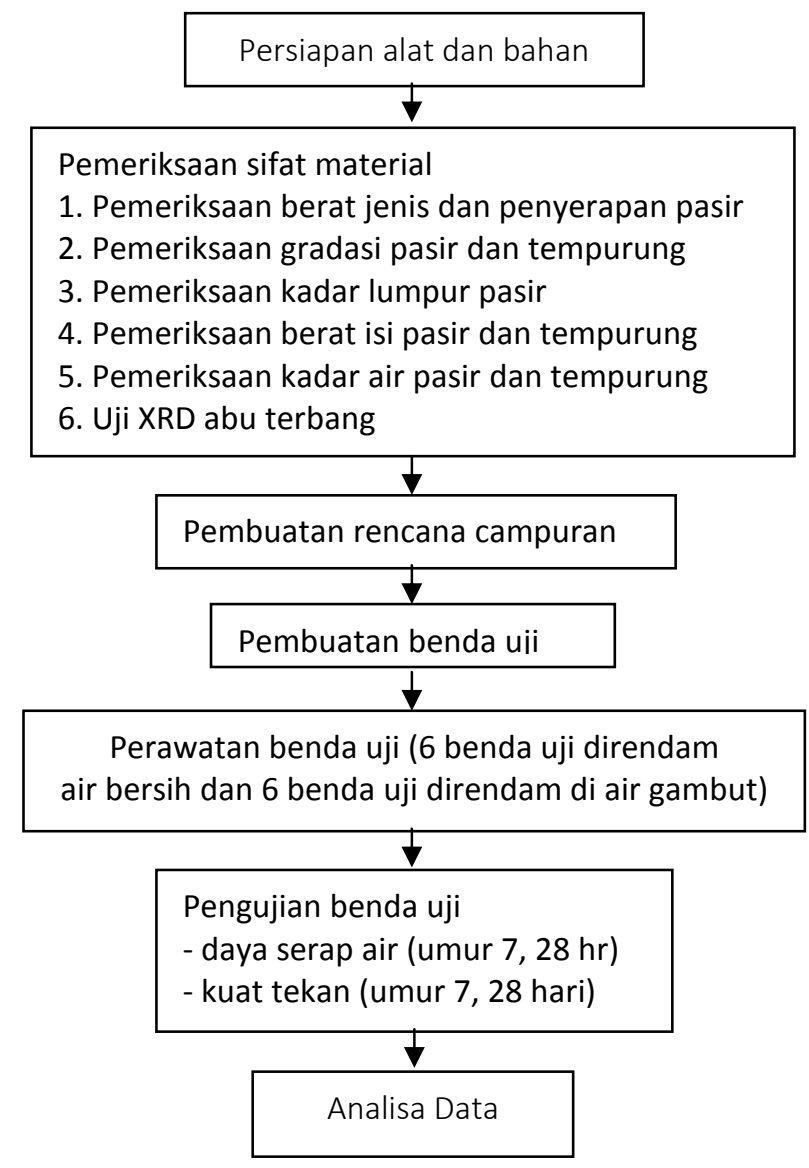

Gambar 1. Diagram Alir Penelitian 
2. Pemeriksaan sifat-sifat bahan susun bata beton diantaranya pemeriksaan XRD abu terbang, pemeriksaan berat jenis dan penyerapan pasir, pemeriksaan gradasi pasir dan tempurung kelapa, pemeriksaan kadar lumpur, dan pemeriksaan berat isi.

3. Pembuatan rencana campuran

Perbandingan semen dan campuran pasir yang digunakan dalam penelitian ini adalah 1:4. Komposisi material dasar bata beton tiap volume $1 \mathrm{~m}^{3}$ memiliki kadar abu terbang sebesar $10 \%$ dari volume semen dan kadar tempurung kelapa sebesar $2 \%$ dari volume pasir untuk campuran.

4. Pembuatan benda uji

Berdasarkan rencana campuran, terdapat hanya 1 buah tipe campuran dengan jumlah benda uji sebanyak 12 benda uji bata beton. Bata beton dibuat langsung dengan menggunakan mesin press bata beton. Uji kuat tekan dilakukan saat benda uji berumur 7 hari dan 28 hari.

5. Perawatan benda uji
Setelah bata beton dikeluarkan dari cetakan dilakukan perawatan dengan cara 6 benda uji direndam pada air gambut, dan 6 benda uji lainnya direndam dalam air biasa. Benda uji akan diangkat 1 hari sebelum dilakukan pengujian.

6. Pengujian benda uji

Pengujian yang dilakukan adalah daya serap air dan uji kuat tekan dengan menggunakan standar SNI 030691-1996 [1]. Kedua jenis pengujian tersebut akan dilakukan pada umur 7 dan 28 hari.

\section{HASIL DAN PEMBAHASAN \\ Hasil Pemeriksaan Abu terbang}

Berdasarkan hasil pengujian XRF pada sampel abu terbang yang digunakan pada penelitian ini, diketahui komposisi kimia seperti terlihat pada Tabel 2. Komposisi kimia berupa $\mathrm{SiO}_{2}, \mathrm{Al}_{2} \mathrm{O}_{3}$, dan $\mathrm{Fe}_{2} \mathrm{O}_{3}$ dengan total sebesar $81.40 \%$ (>50\%) sedang komposisi $\mathrm{CaO}$ sebesar $11.3 \%$ $(>10 \%)$, sehingga abu terbang yang digunakan tersebut dapat dimasukan dalam tipe C berdasarkan ASTM C618 [7].

Tabel 1. Komposisi kimia Abu terbang

\begin{tabular}{cccc}
\hline Komposisi Kimia & Persentase (\%) & Komposisi Kimia & Persentase (\%) \\
\hline $\mathrm{SiO}_{2}$ & 27 & $\mathrm{~V}_{2} \mathrm{O}_{5}$ & 0.05 \\
$\mathrm{Al}_{2} \mathrm{O}_{3}$ & 7.20 & $\mathrm{Cr}_{2} \mathrm{O}_{3}$ & 0.03 \\
$\mathrm{Fe}_{2} \mathrm{O}_{3}$ & 47.2 & $\mathrm{MnO}$ & 0.66 \\
$\mathrm{CaO}$ & 11.3 & $\mathrm{CuO}$ & 0.06 \\
$\mathrm{MgO}$ & 0.84 & $\mathrm{ZnO}$ & 0.09 \\
$\mathrm{~K}_{2} \mathrm{O}$ & 0.56 & $\mathrm{MoO}_{3}$ & 2.6 \\
$\mathrm{TiO}_{2}$ & 0.84 & $\mathrm{BaO}$ & 0.69 \\
$\mathrm{P}_{2} \mathrm{O}_{5}$ & 0.47 & $\mathrm{Re}_{2} \mathrm{O}_{7}$ & 0.40 \\
\hline
\end{tabular}

Sumber: Hasil Pengujian XRF, 2019

\section{Hasil Pemeriksaan Air}

Air diperlukan pada pembuatan bata beton untuk memicu proses kimiawi semen, untuk membasahi agregat dan akan memberikan kemudahan pada adukan bata beton, dalam penelitian ini, air digunakan secara visual dalam kondisi jernih dan tidak berbau.

\section{Hasil Pemeriksaan Semen}

Semen yang digunakan dalam penelitian ini adalah semen PCC merk Tiga Roda dengan isi perkemasan $40 \mathrm{~kg}$. Keadaan semen dalam keadaan baik, untuk kemasan juga tertutup rapat dan keadaan semen bagus dan tidak mengalami penggumpalan.

\section{Hasil Pemeriksaan Agregat Halus}

Dari serangkaian pemeriksaan yang dilakukan terhadap agregat halus didapatkan bawa pasir mempunyai nilai modulus kehalusan antara 1,5-3,8 dikategorikan sebagai pasir yang baik dan memenuhi syarat untuk digunakan sebagai campuran beton berdasarkan SNI S-04-1989 [8]. Dari hasil pemeriksaan pasir, modulus kehalusan butiran adalah 2,36 sehingga pasir tersebut dapat digunakan untuk campuran beton dan termasuk gradasi nomor 2 menurut SNI 03-2834-2000 [9]. Kadar lumpur adalah 1.53\% menurut SNI S-04-1989 [8] kadar lumpur di bawah 5\% dapat digunakan langsung untuk material beton, maka material pasir pada penelitian ini dapat digunakan sebagai material bata beton tanpa harus dicuci terlebih dahulu.

\section{Pemeriksaan Gradasi Tempurung Kelapa}

Tempurung kelapa yang digunakan dalam penelitian ini telah dibersihkan dan dipisahkan dari serat-serat yang menempel, kemudian tempurung kelapa ditumbuk dan diayak sehingga lolos ayakan ukuran $5 \mathrm{~mm}$.

\section{Pemeriksaan Air Gambut}


Air gambut digunakan untuk perendaman diambil dari wilayah Palangka Raya, Kalimantan Tengah. Hasil pemeriksaan $\mathrm{pH}$ memperlihatkan air tersebut asam

Tabel 2. Pemeriksaan air gambut

\begin{tabular}{ll}
\hline Uraian & Hasil \\
\hline $\mathrm{pH}$ & 3.92 \\
Warna & 380 \\
Kandungan organic & 386 \\
\hline
\end{tabular}

Sumber: Hasil Penelitian, 2019

\section{Desain Campuran Bata Beton}

Bolomey merumuskan bahwa kuat tekan beton ditentukan oleh kekuatan mortar, faktor semen air, dan jumlah agregat dalam campuran beton. Metode ini dikembangkan lebih lanjut oleh Dreux Gorisse yang berkebangsaan Perancis melalui penelitian yang dilakukannya tahun 1979 [10].

Tabel 3. Komposisi campuran $1 \mathrm{~m}^{3}$ bata beton

\begin{tabular}{lc}
\hline \multicolumn{1}{c}{ Bahan Campuran } & Volume (SSD) \\
\hline Semen & 258.75 \\
Abu terbang & 28.75 \\
Pasir & 1405.6 \\
Tempurung kelapa (20\%) & 351.4 \\
Air & 220 \\
\hline
\end{tabular}

Sumber: Hasil Penelitian, 2019

\section{Hasil Pengujian Kuat Tekan Bata Beton}

Bata beton dicampur langsung dengan menggunakan mesin pencetak bata beton dengan sistem press. Benda uji yang dibuat untuk pengujian kuat tekan sebanyak 12 buah, dimana 6 benda uji direndam di air dengan $\mathrm{pH}$ sebesar 3.92 (Tabel 2). Air diganti setiap 1 minggu untuk memastikan bahwa $\mathrm{pH}$ stabil selama masa perendaman.
Tempurung kelapa yang digunakan sebesar 20\%, berdasarkan hasil penelitian Zaini Indra Fahmi (2019) yang menyatakan bahwa penambahan tempurung kelapa sebesar 20\% dan abu terbang 2,5\% menghasilkan kuat tekan bata beton maksimum dan daya serap air yang minimum

Tabel 4. Nilai kuat tekan bata beton

\begin{tabular}{ccccccccc}
\hline Kode Sampel & \multicolumn{3}{c}{ Umur 7 hari $\left(\mathrm{kg} / \mathrm{m}^{2}\right)$} & \multicolumn{4}{c}{ Umur 28 hari $\left(\mathrm{kg} / \mathrm{m}^{2}\right)$} \\
\cline { 2 - 9 } & 1 & 2 & 3 & Rerata & 1 & 2 & 3 & Rerata \\
\hline M-1 & 7.8 & 6.1 & 7.75 & 7.22 & 10.1 & 11.95 & 10.5 & 10.85 \\
M-2 & 7.2 & 7.3 & 6.8 & 7.1 & 10.3 & 10.5 & 11.1 & 10.63 \\
\hline
\end{tabular}

Sumber: Hasil Penelitian, 2019

M-1 = Bata beton yang direndam pada air biasa

M-1 = Bata beton yang direndam pada air gambut

Tabel 4 memperlihatkan hasil perhitungan nilai kuat tekan rata-rata bata beton yang direndam pada rendaman air gambut dengan waktu rendaman 7 dan 28 hari masing-masing sebesar $7.1 \mathrm{~kg} / \mathrm{m}^{2}$ dan $10.63 \mathrm{~kg} / \mathrm{m}^{2}$. Sedangkan untuk rendaman air biasa dengan waktu rendaman 7 dan 28 hari berturut-turut sebesar 7.22 $\mathrm{kg} / \mathrm{m}^{2}$ dan $10.85 \mathrm{~kg} / \mathrm{m}^{2}$. Secara umum dapat disimpulkan, pada masing-masing campuran terdapat peningkatan kekuatan bata beton dari umur 7 hari ke umur 28 hari biasa dan 6 benda uji direndam di air gambut selama 7 dan 28 hari. Benda uji tersebut diangkat dari rendaman 1 hari (24 jam) sebelum dilakukan pengujian. Pengujian kuat tekan bata beton dilakukan dengan mengikuti prosedur yang ditentukan di dalam SNI 03-0691-1996 [1].
[12]. Hal tersebut terjadi karena adanya reaksi hidrasi pada semen. Penambahan abu terbang pada campuran akan memberikan kontribusi pada kekuatan bata beton akibat dari kombinasi antara hidrasi semen dan reaksi pozzolan $[13,14]$

Pada bata beton yang direndam dalam air gambut, nilai kuat tekan yang dihasilkan hanya sedikit lebih kecil dibandingkan nilai kuat tekan bata beton yang direndam menggunakan air biasa pada umur 7 dan 28 hari. Artinya, 
penggunaan abu terbang dan tempurung kelapa dapat membuat pori-pori bata beton semakin kecil, sehingga pengaruh rendaman dengan air gambut yang digunakan bersifat asam $(\mathrm{pH}=3.92)$ tidak terlalu mempunyai efek yang signifikan terhadap kekuatan tekan batu beton. Asam yang terkandung dalam air gambut tersebut tersebut mempunyai efek yang dapat merusak kekuatan semen [15], tetapi pada campuran penelitian ini, fenomena tersebut tidak signifikan terlihat.

\section{Hasil Pengujian Daya Serap Air}

Benda uji yang dibuat untuk pengujian daya serap air sebanyak 12 buah, dimana 6 benda uji direndam di air biasa dan 6 benda uji direndam di air gambut selama 7 dan 28 hari. Pengujian daya serap air bata beton dilakukan dengan mengikuti prosedur yang ditentukan di dalam SNI 03-0691-1996 [1]. Tabel 5 memperlihatkan hasil pengujian daya serap air pada benda uji.

Tabel 5. Daya serap air bata beton

\begin{tabular}{ccccccccc}
\hline Kode Sampel & \multicolumn{4}{c}{ Umur 7 hari (\%) } & \multicolumn{4}{c}{ Umur 28 hari (\%) } \\
\cline { 2 - 9 } & 1 & 2 & 3 & Rerata & 1 & 2 & 3 & Rerata \\
\hline M-1 & 9.20 & 6.75 & 8.02 & 7.99 & 7.88 & 7.36 & 7.41 & 7.55 \\
M-2 & 8.42 & 7.71 & 7.23 & 7.79 & 7.90 & 8.01 & 8.25 & 8.05 \\
\hline
\end{tabular}

Sumber: Hasil Penelitian, 2019

Tabel 5 memperlihatkan bahwa daya serap air pada benda uji bata beton yang direndam pada air biasa dan air gambut menunjukkan hasil yang tidak jauh berbeda, yaitu masing-masing sebesar 7,99\% dan $7.79 \%$. Sedangkan pada umur 28 hari, terjadi peningkatan daya serap air sedikit lebih tinggi pada benda uji yang direndam dengan air gambut yaitu $8.05 \%$, sedangkan pada benda uji yang direndam pada air biasa terjadi penurunan daya serap menjadi $7.55 \%$.

Sifat asam dari air gambut merusak permukaan beton, bahan-bahan organik tersebut akan hinggap dan bertahan di pori-pori beton dan berpotensi menutup poripori tersebut sehingga kerusakan beton tidak sampai ke dalam bata beton sehingga dapat mengurangi daya serap air pada umur 7 hari. Pada umur 28 hari, hasil di rendaman air gambut menunjukkan peningkatan daya serap air disbanding umur 7 hari, hal ini terjadi akibat proses perusakan asam dari air gambut yang terus masuk ke dalam beton dan menggangu proses hidrasi serta merusak produk hidrasi tersebut. Hal ini menyebabkan perbesaran pori beton dan berpotensi besar untuk mempermudah serangan asam masuk lebih dalam lagi ke dalam beton [16]

\section{Hubungan antara Nilai Kuat Tekan dan Daya Serap Air}

Hasil pengujian kuat tekan dan daya serap air bata beton pada umur 7 hari dan 28 hari pada benda uji dengan direndam pada air biasa dan pada air gambut memperlihatkan beberapa karakteristik sebagai berikut:

1. Pada bata beton yang direndam pada air biasa, seiring dengan peningkatan umur bata beton, maka kuat tekan beton meningkat, dan daya serap air menurun.

2. Pada bata beton yang direndam pada air gambut, seiring dengan peningkatan umur bata beton, maka kuat tekan beton menurun, dan daya serap air meningkat.

\section{KESIMPULAN DAN SARAN Kesimpulan}

Kesimpulan hasil penelitian yang sudah dilakukan antara lain:

1. Pada bata beton dengan menggunakan abu terbang dan tempurung kelapa dan direndam pada air biasa, memperlihatkan karakteristik dimana seiring dengan peningkatan umur bata beton, maka kuat tekan beton meningkat, dan daya serap air menurun.

2. Pada bata beton dengan menggunakan abu terbang dan tempurung kelapa dan direndam pada air gambut, memperlihatkan karakteristik dimana dengan peningkatan umur bata beton, maka kuat tekan beton menurun, dan daya serap air meningkat.

3. Kuat tekan pada benda uji bata beton yang direndam dengan air biasa dan air gambut memperlihatkan nilai yang relatif sama pada umur 7 dan 28 hari.

4. Daya serap air pada benda uji bata beton yang direndam dengan air biasa dan air gambut memperlihatkan nilai yang relatif sama pada umur 7, tetapi pada umur 28 hari, benda uji yang direndam dengan air gambut mempunyai daya serap air yang lebih besar dibanding dengan yang direndam pada air biasa.

\section{Saran}

Beberapa saran yang dapat diberikan dari hasil penelitian antara lain:

1. Perlu dilakukan pengujian pada umur di atas 28 hari, sehingga dapat diketahui karakteristik jangka panjang.

2. Perlu dilakukan penelitian sifat mekanik dan durabilitas bata beton dengan pengujian yang lebih kompleks.

\section{DAFTAR PUSTAKA}

[1] Badan Standarisasi Nasional. 1996. (SNI 03-06911996) Bata Beton (Paving block). Jakarta.

[2] PT Duta Prokal Multimedia. 2018. diakses 20 November 2018. Proyek PLTU Kalteng-1 Dimulai Ditargetkan Siap Beroperasi Tahun 2019, 
http://sampit.prokal.co/read/news/16904-proyekpltu-kalteng-1-dimulai.html.

[3] Munir, M. 2008. Fly Ash Utilization for Hollow Block Quality and Safe for the Environment. Thesis. University of Diponegoro.

[4] Megasari, K., Deni S., dan Mari C. P. 2008. Penakaran Daur Hidup Pembangkit Listrik Tenaga Uap (PLTU) Batubara Kapasitas 50 MWatt. Seminar Nasional IV SD Teknologi Nuklir. STTNBatan. Yogyakarta.

[5] Kristanto, Anton dan Saputra, Salim Himawan. 2003. Penggunaan fly ash untuk pembuatan paving block. Bachelor thesis, Petra Christian University. Surabaya.

[6] Hartanto, Kukuh. 2014. Pemanfaatan Limbah Pecahan Tempurung Kelapa Sebagai Bahan Tambah Pada Campuran Bahan Baku Batako. Skripsi thesis, Universitas Muhammadiyah Surakarta.

[7] ASTM C 618. 2003. Standard Spesification for Pozzolanic Material. ASTM USA.

[8] Departemen Pekerjaan Umum. 1989. SK SNI S-041989-F: Spesifikasi Bahan Bangunan Bagian A (Bahan Bangunan Bukan Logam). Bandung: Yayasan LPMB.

[9] SNI 03-2834-2000. Tata Cara Pembuatan Rencana Campuran Beton Normal. Pusat Penelitian dan Pengembangan Teknologi Permukaan, Jakarta.
[10] Thesia, Z. 2013. Studi Mengenai Perancangan Campuran Beton Cara Dreux Gorisse-ITENAS. Tugas Akhir. Bandung: Jurusan Teknik Sipil Institut Teknologi Nasional

[11] Famhi, I. Z. 2019. Kuat Tekan dan Daya Serap Air Pada Paving Block Menggunakan Limbah Tempurung Kelapa dan Fly Ash. Skripsi. Universitas Palangka Raya.

[12] Tri Mulyono. 2005. Teknologi Beton. Penerbit ANDI, Yogyakarta.

[13] Jackson, N. 1977. Civil Engineering Material. Great Britain, Unwin Brothers, England.

[14] Munir, M. 2008. Pemanfaatan Abu Batubara (Fly Ash) untuk Hollow Block yang Bermutu dan Aman bagi Lingkungan. Tesis. Universitas Diponegoro, Semarang.

[15] Wianto, T., Haryanti, N. H. 2007. Analisis Pengaruh Air Gambut dan Aquades Terhadap Kuat Tekan pada materials semen. J. Sains MIPA, Agustus 2007, Vol. 13, No. 2, pp.113 -116. http://jurnal.fmipa.unila.ac.id/index.php/sains/arti cle/view/68/0

[16] Pandiangan, J. A., Olivia, M., Darmayanti, L. 2014. Ketahanan Beton Mutu Tinggi di Lingkungan Asam. Jurnal Online Mahasiswa Fakultas Teknik Universitas Riau, Februari 2014. https://www.neliti.com/id/publications/201070/ke tahanan-beton-mutu-tinggi-di-lingkungan-asam. 